\title{
Serum malondialdehyde-like material (MDA-LM) in acute myocardial infarction
}

\author{
JUSTO AZNAR,* M TERESA SANTOS, $\dagger$ JUANA VALLES, $\dagger$ JESUS SALA*
}

From the *Departments of Clinical Pathology and †Research Center, Ciudad Sanitaria "La Fe", Valencia, $\overrightarrow{0}$ Spain

SUMMARY Serum malondialdehyde-like material (MDA-LM), as an index of lipid peroxidation, ? and the serum enzymes CK, CK-MB, LDH, $\mathrm{LDH}_{1}$ and, $\alpha-\mathrm{HBDH}$ were evaluated in a group of $\mathscr{\omega}^{\mathrm{W}}$ 26 patients with acute myocardial infarction (AMI), seven with angina pectoris (AP), and in a normal control group of 94 subjects. MDA-LM values were within the normal range in AP $\overrightarrow{\mathrm{N}}$ patients, while in AMI patients a significant increase in serum MDA-LM was observed in the $ᄋ$ days following the acute event, reaching a maximum 6-8 days later, when $90 \%$ of the patients $\rightarrow$ had values higher than the upper normal limit (mean $\pm 2 \mathrm{SD}$ ) of the control group.

A significant correlation was found between the integrated concentration-time MDA-LM curve and the integrated serum enzymes activity curves reached during the nine days after the $\vec{\oplus}$ acute event.

The "in vivo" relevance of the increased serum MDA-LM in the post-infarct period is unknown at the present, but as lipid peroxides are known to harm cellular structures and to inhibit prostacyclin synthesis, it may be of interest with regard to the long term secondary effects in AMI patients.

Malondialdehyde is a known stable product of lipid peroxidation. ${ }^{12}$ Therefore, the evaluation of the malondialdehyde-like material (MDA-LM) by the thiobarbituric acid reaction may be used to decide whether a process of lipid peroxidation has taken place.

Lipid peroxidation is thought to be involved in various pathological conditions, among others, platelet activation, ${ }^{3}$ tissue destruction ${ }^{4}$ and various inflammatory processes. ${ }^{5}$

Since acute myocardial infarction (AMI) may be related to a thromboembolic process, ${ }^{6}$ to tissular destruction, and to a secondary inflammatory process, it seemed reasonable to expect a raised MDA-LM concentration in the serum of the patients. In order to evaluate this possibility, serum MDA-LM was quantified in a group of AMI patients.

\section{Material and methods}

MDA-LM values were studied in a population of 94 normal fasting subjects between the ages of 23 and $70(40$ men, mean $=45 \mathrm{yr}$, and 54 women, mean $=$

Accepted for publication 17 January 1983
$42 \mathrm{yr}$ ), from the Preventive Medicine Clinic in our $\stackrel{\overline{3}}{\exists}$ Hospital, all without cardiovascular or haematological complications and without diabetes, dislipaemiaso or other metabolic disorders. All control subjects studied denied having received any medication? known to modify platelet function in the 15 days prior to sampling.

\section{PATIENTS}

Thirty-three patients were studied, They were $>$ classified into two groups: 26 patients with AMI (17) men, mean $=55 \mathrm{yr} ; 9$ women, mean $=60 \mathrm{yr}$ ), and No seven patients with angina pectoris (AP) (4 men, mean $=49 \mathrm{yr} ; 3$ women, mean $=65 \mathrm{yr}$ ), diagnosed according to usual electrocardiographic, enzymatic $\omega$ and clinical criteria. ${ }^{7}$ The only criterion for admission of the patients into the study was the diagnosis of AMI or AP during the time the project was being carried out.

Samples were taken from the cubital vein of each patient on various days from the time of their admis- $\frac{\text { P }}{\mathbb{D}}$ sion up to nine days afterwards in the case of AMI patients, and up to four days after admission in the case of AP patients.

In order to study the daily evolution of the 


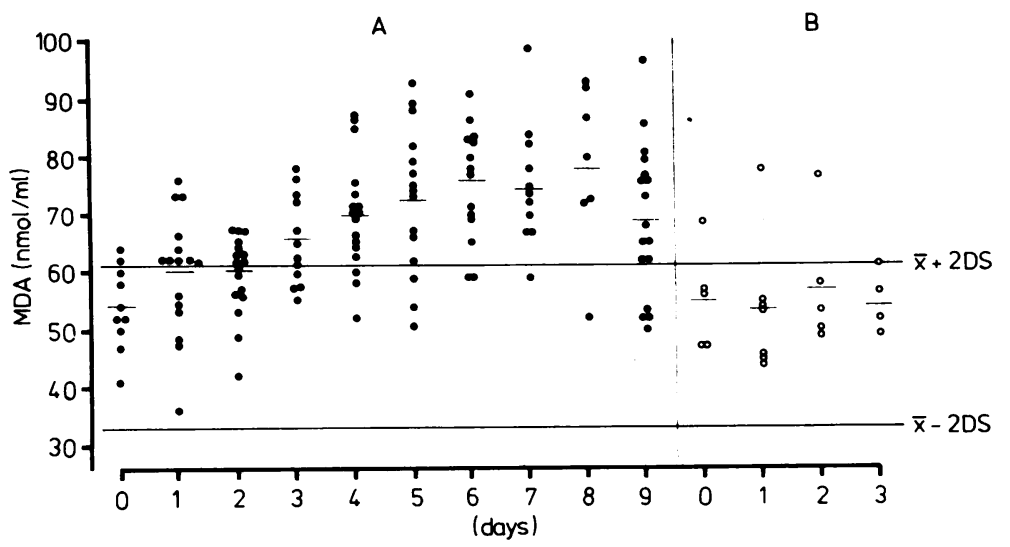

Fig. $1 M D A-L M$ values (nmol/ml) on the days following the acute event in a group of patients with acute myocardial infarction $(A)$ and angina pectoris $(B)$. Zero $(0)$ corresponds to determinations performed less than $24 h$ after the onset of the precordial pain. Mean $\pm 2 S D$ is the discrimination limit of the MDA-LM level found in the 94 control subjects studied $(47.18 \pm 6.96 \mathrm{nmol} / \mathrm{ml})$

patients and to locate the correct timing of the determinations, the zero reference point was taken to be the moment the precordial pain appeared, according to the patient's statement.

The MDA-LM was evaluated by the thiobarbituric acid reaction according to the method previously described. $^{8}$

Concentrations of serum creatinine kinase (EC 2.7.3.2) (CK), ${ }^{9}$ lactate dehydrogenase (EC 1.1.1.27) $(\mathrm{LDH})^{10}$ and $\alpha$-hydroxybutyric dehydrogenase (EC 1.1.1.30) $(\alpha-\mathrm{HBDH})^{11}$ were evaluated in an LKB 8.200 Autoanalyzer.

Serum CK and LDH isoenzymatic activities were determined as described previously by Elevitch ${ }^{12-14}$

Plasma values of MDA-LM from normal subjects were arranged in a percentile cumulative frequency. Linear correlation and Simson's curve integration method were used for statistical analysis.

\section{Results}

The mean value of serum MDA-LM in the control group was mean $=47 \cdot 18, \mathrm{SD}=6.96 \mathrm{nmol} / \mathrm{ml}$. The mean serum MDA-LM concentations in the AMI and AP patients within $24 \mathrm{~h}$ of the onset of the precordial pain were within the normal control range in both groups (Fig. 1), while on the days after the acute event an increase in the serum MDA-LM was observed in the AMI patients, reaching its maximum on the eighth day (Fig. 1). The values of the AP patients did not vary significantly and were within the normal control range on the days the determinations were performed (Fig. 1).
The percentage of patients having MDA-LM concentrations higher than $61 \mathrm{nmol} / \mathrm{ml}$, taken as the upper normal limit in this laboratory (upper normal limit $=$ mean $\pm 2 S D$ ) increases to a maximum of $90 \%$ on the seventh and eighth days. The percentage of AP patients with serum MDA-LM concentrations higher than $61 \mathrm{nmol} / \mathrm{ml}$ after the acute crisis, was much lower than that of the AMI patients, with no apparent increase over the days after the acute event as in the AMI patients (Fig. 1).

With the object of evaluating the possible relation between the serum MDA-LM concentrations observed in the AMI patients with the cardiac lesion, the enzyme activities-time curves of CPK, $\mathrm{LDH}$, and $\alpha-\mathrm{HBDH}$ and the concentration-time MDA-LM curve were studied in 21 of the AMI patients from the acute event up to the ninth day after (Fig. 2). The MDA-LM concentration and the enzyme activities show a distinct pattern of evolution during the days after the acute event. However, when we studied the possible linear correlation between the integrated areas of the enzyme activitiestime curves and the integrated concentration-time MDA-LM curve (Table), a statistically significant correlation was found between the integrated concentration-time MDA-LM curve and the integrated activities-time curves of $\mathrm{CPK}, \mathrm{LDH}$, $\alpha-\mathrm{HBDH}$, as well as that of the isoenzyme $\mathrm{LDH}_{1}$. A statistically significant correlation $(r=0.562,0.01$ $>p>0.001)$ was also found between the integrated curves of serum MDA-LM concentration and CK-MB activity obtained in the days when the CK-MB activity was other than zero. 
Table Integrated areas under the MDA-LM concentration-time and enzymes activity-time curves of each of the AMI patients studied

\begin{tabular}{|c|c|c|c|c|}
\hline$M D A$ & $C P K$ & $L D H$ & $\mathrm{LDH}_{1}^{\dagger}$ & $\alpha-H B D H$ \\
\hline $\begin{array}{c}921 \cdot 84 \\
534.91 \\
679.80 \\
112.46 \\
583.14 \\
405.99 \\
552.36 \\
640.6 \\
518.54 \\
1388.72 \\
487.91 \\
116.76 \\
338.07 \\
807.95 \\
573.07 \\
496.55 \\
146.07 \\
594.44 \\
793.07 \\
347.08 \\
\end{array}$ & $\begin{array}{c}462 \cdot 5 \\
882 \cdot 5 \\
1555 \cdot 5 \\
178 \\
736 \\
306 \cdot 2 \\
681 \cdot 6 \\
1207 \\
434 \\
1777 \cdot 8 \\
346 \cdot 5 \\
242 \\
591 \cdot 5 \\
174 \cdot 5 \\
510 \\
1179 \cdot 5 \\
455 \cdot 5 \\
575 \\
912 \\
466.5\end{array}$ & $\begin{array}{c}3789 \\
11551 \cdot 5 \\
9854 \\
590 \\
5671 \\
4415 \cdot 5 \\
4787 \cdot 5 \\
5424 \cdot 5 \\
3556 \cdot 5 \\
9245 \cdot 5 \\
3026 \\
1582 \\
3201 \\
4090 \\
4440 \\
5047 \\
4405 \\
3648 \\
8141 \\
2283 \cdot 5\end{array}$ & $\begin{array}{l}425 \\
364 \\
585 \cdot 5 \\
54 \cdot 5 \\
330 \\
305 \cdot 5 \\
366 \cdot 5 \\
347 \\
365 \\
461 \cdot 5 \\
330 \\
66 \cdot 5 \\
182 \cdot 5 \\
323 \\
241 \cdot 5 \\
301 \cdot 5 \\
76 \cdot 5 \\
272 \\
473 \cdot 5 \\
167 \cdot 5 \\
\end{array}$ & $\begin{array}{l}1905 \\
223 \\
6772 \\
290 \\
4021 \cdot 5 \\
2942 \\
2676 \cdot 5 \\
2930 \\
2166 \\
6426 \\
3554 \cdot 5 \\
891 \cdot 5 \\
2018 \\
2276 \\
2654 \cdot 5 \\
2520 \cdot 5 \\
1103 \\
2266 \\
5292 \\
1250\end{array}$ \\
\hline $\begin{array}{l}\text { MDA/CPK } \\
\text { MDA/LDH } \\
\text { MDA/LDH } \\
\text { MDA/HBDH }\end{array}$ & $\mathrm{r}=0.612^{*}$ & $r=0.575^{*}$ & $\mathrm{r}=0.785^{* *}$ & $r=0.676^{* *}$ \\
\hline
\end{tabular}

$r=$ linear correlation coefficient between MDA-LM concentration-time and enzyme activity-time curves integrated areas.

${ }^{*} 0.01>p>0.001 \quad *{ }^{*} p<0.001$

†Activity referred to percentage of total LDH.

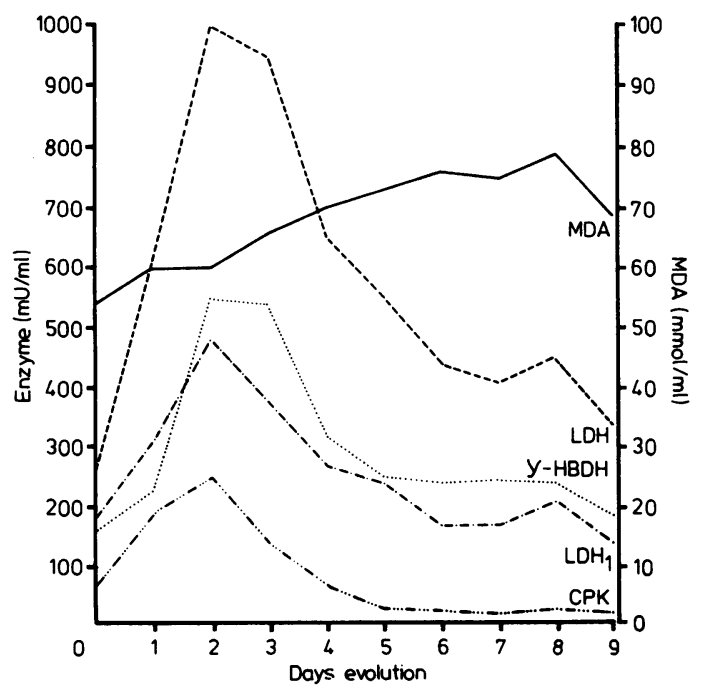

Fig. $2 M D A-L M$ concentration ( $\mathrm{nmol} / \mathrm{ml})$-time curve and enzyme activity ( $m U / l)$-time curves of $C K, C K-M B, L D H$, $L D H_{1}$ and $\alpha-H B D H$ on the nine days following the acute event.

\section{Discussion}

The results show that within 24 hours of the appearance of the precordial pain the serum MDA-LM concentrations in the AMI and AP patients, although slightly higher, are within the range of the normal control group. The fact that the MDA-LM concentrations progressively increase during the days following the acute event, reaching maximum $\overrightarrow{\overrightarrow{0}}$ values in 6-8 days, suggests that the increase is sec 3 ondary to the acute crisis; this MDA-LM increase could be related to the myocardial lesion or in general to the alterations which are secondary to AMI

If one considers that the activities of the serumb enzymes related to cardiac damage have a relation. with the size of the lesion, ${ }^{15}$ the correlation found between the integrated area of the MDA-LMB concentration-time curve and cardiac enzymeso activity-time curves could suggest a certain relation between MDA-LM and cardiac damage.

The origin of this increase in MDA-LM is unknown, although it may be related to an increase in prostaglandin synthesis, ${ }^{16}$ since processes such as myocardial ischaemia, ${ }^{17}$ hypoxia, ${ }^{18}$ inflammatory processes $^{19}$ and platelet aggregation, ${ }^{3}$ circumstances which may occur in AMI patients have been reported to cause an increase in prostaglandin release; however other mechanisms of lipid peroxi告 dation cannot be excluded.

It has been shown that lipid peroxides ${ }^{20}$ and the stable breakdown product of lipid peroxidation MDA $^{2122}$ could be transported by low density lipo proteins (LDL), and also that the MDA bound to LDL favour the incorporation of cholesterol esters 
in the cells of the atherosclerotic reaction. ${ }^{22}$ Additionally, lipid peroxides are known to harm cellular and tissular components ${ }^{23} 24$ and to inhibit prostacyclin biosynthesis. ${ }^{25}$ Therefore, the observed increase in serum MDA-LM in AMI patients may be an additional risk factor in those subjects as the possible incorporation of lipid peroxides into the arterial wall could reduce the vascular antiaggregant defence and could favour the development of the atherosclerotic lesion. Although further investigations are needed to assess the biological and long term significance of the observed increase in MDA-LM in AMI patients, the inclusion of an antioxidant might be reasonably considered in the therapeutic treatment of those patients.

We acknowledge the technical assistance of Miss Rosa M Ferrer and Miss Carmen Insa.

This work was supported by a grant No. $12 / 423 / 78$ from the Instituto Nacional de Prevision.

\section{References}

' Placer ZA, Cushman LL, Johnson BC. Estimation of product of lipid peroxidation (Malonyldialdehyde) in biochemical systems. Anal Biochem 1966;16:359-64.

${ }^{2}$ Porter NA, Prostaglandin endoperoxides. In: Prior WA, ed. Free radicals in biology. New York: Academic Press, 1980:261-94.

${ }^{3}$ Smith JB, Ingerman CM, Silver MJ. Malondialdehyde formation as an indicator of prostaglandin production by human platelets. J Lab Clin Med 1976;88:167-72.

4 Flamm ES, Demopoulos HB, Seligman ML, Poser RG, Ransohoff J. Free radicals in cerebral ischemia. Stroke 1978;9:445-7.

${ }^{5}$ Bragt PC, Bansberg JI, Bonta IL. Antiinflammatory effects of free radical scavengers and antioxidants. Further support for proinflammatory roles of endogenous hydrogen peroxide and lipid peroxides. Inflammation 1980;4:289-99.

${ }^{6}$ Harker LA, Ritchie JL. The role of platelets in acute vascular events. Circulation 1980;62 suppl v:13-8.

' Ischaemic Heart disease registers: report of the fifth working group. Copenhagen, Denmark: WHO, 1971.

santos MT, Valles J, Aznar J, Vilches J. Determination of the plasma malondialdehyde-like material (MDA-LM) and its clinical application in stroke patients. J Clin Pathol 1980;33:973-6.

9 Forster G, Bernt E, Bergmeyer HU. Creatine kinase. In: Methoden der enzymatischen Analyse. Weinheim 2, Antlage: Verlag chemie, 1970:784-97.
${ }^{10}$ Wroblewski G, La Due JS. Lactic dehydrogenase activity in blood. Proc Soc Exp Biol Med 1955;90:210-3.

"Rosalki SB, Wilkinson JH. Reduction of $\alpha$-ketobutyrate by human serum. Nature 1960;188:1110-1.

${ }^{12}$ Elevitch GR, Brownlow K. A new fluorometric determination of serum creatine phosphokinase isoenzymes: detection of $\mathrm{CPK}_{2}$ in myocardial infarction and fatal cardiovascular disorders. Am J Clin Pathol 1973;59:133-4.

${ }^{13}$ Elvitch GR, Aronston SB, Feichtmeir TV, Enterline ML. Thin gel electrophoresis in agarosa. Am J Clin Pathol 1966;46:692-7.

14 Elevitch GR. Lactate dehydrogenase isoenzymes. In: Fluorometric techniques in clinical chemistry. Boston: Little Brown and Co, 1973:223-33.

is Witheveen SAG, Hemiber HC, Itollaar LTH, Hesmens W. Quantitation of infarct size in man by means of plasma enzyme levels. Br Heart J 1975;37:795.

${ }^{16}$ Shimizu T, Kondo K, Hayaishi O. The role of prostaglandin endoperoxides in the serum thiobarbituric acid reaction. Arch Biochem Biophys 1981;206:271-6.

${ }^{17}$ Berger HJ, Zaret BL, Speroff L, Cohen LS, Wolfson S. Cardiac prostaglandin release during myocardial ischemia induced by atrial pacing in patients with coronary artery disease. Am J Cardiol 1977;39:481-6.

18 Wennmalm A, Chanh PH, Justand M. Hypoxia causes prostaglandin release from perfused rabbit hearts. Acta Physiol Scand 1974;91:133-5.

19 Kuehl FA, Humes JL, Egan RW, Ham EA, Beveridge GC, Van Arman CG. Role of prostaglandin endoperoxide $\mathrm{PGG}_{2}$ in inflammatory processes. Nature 1977;265:170-3.

${ }^{20}$ Szceklik A, Gryglewski RJ, Domaglae B, et al. Serum lipoproteins, lipid peroxides and prostacyclin biosynthesis in patients with coronary heart disease. Prostaglandins 1981;22:795-807.

${ }^{21}$ Brown MS, Basu SK, Falcky JR, Ho YK, Goldstein JL. The scavenger cell pathway for lipoprotein degradation: specificity of the binding site that mediates the uptake of negativelycharged LDL by macrophages. J Supramol Struct 1980;13:67-81.

${ }^{22}$ Fogelman AM, Shechter I, Seager J, Holom M, Child JS, Edwards PA. Malondialdehyde alteration of low density lipoproteins leads to cholesteryl ester accumulation in human monocyte-macrophages. Proc Natl Acad Sci USA 1980;77:2214-8.

${ }^{23}$ Tappel AL. Lipid peroxidation damage to cell components. Fed Proc 1973;32:1870-4.

${ }^{24}$ Kontos HA, Wei EP, Poulishock JT, Dietrich WD, Magiera CJ, Ellis EF. Cerebral arteriolar damage by arachidonic acid and prostaglandin $G_{2}$. Science 1980;209:1242-5.

${ }^{25}$ Gryglewski RJ. Prostaglandins, platelets and atherosclerosis. CRC Crit Rev Biochem 1980;7:291-338.

Requests for reprints to: Dr Justo Aznar, Departamento de Biopatologia Clínica, Ciudad Sanitaria "La Fe", Avda Campanar, 21, Valencia - 9, Spain. 